\title{
Governing Climate Change Risks: Subnational Climate Policies in Brazil
}

\author{
Fabiana Barbi ${ }^{1}$ (D) Leila da Costa Ferreira ${ }^{1}$
}

Received: 25 January 2017/ Accepted: 27 February 2017/Published online: 6 March 2017

(C) Fudan University and Springer Science+Business Media Singapore 2017

\begin{abstract}
Subnational governments play a key role producing responses to climate change risks involving policy strategies and instruments. This article analyzes how Brazilian municipal and state governments have developed and implemented climate change mitigation and adaptation public policies. We surveyed all cities' and states' climate policies within the country. The methodological approach includes five main points of analysis: (1) mitigation targets and intentions; (2) adaptation actions; (3) stakeholders' participation; (4) policy implementation; (5) participation in climate change transnational networks. Our results showed that even though subnational climate policies are isolated initiatives in the country, they are relevant initiatives to respond to climate change risks in different scales and levels. The solidest subnational policies emerged where there were previous institutional arrangements related to climate change including the participation of several stakeholders. Such governments have also joined transnational climate change cooperation networks.
\end{abstract}

Keywords Adaptation · Brazil · Climate change policy · Mitigation · Risks

\section{Introduction}

Climate change affects people around the world causing great loss of human lives, disturbing the economy, agriculture, health and seriously impacting ecosystems. Climate change impacts affect water and food availability and social and natural systems, threatening relevant development issues (WMO 2013; Zwiers et al. 2013;

Fabiana Barbi

fabarbi@gmail.com

1 Center for Environmental Studies and Research, University of Campinas, Campinas, Brazil 
IPCC 2013). Societies worldwide are challenged to respond to climate change risks and increasing threats arising from changes in the climatic system.

Climate change risks can be interpreted as contemporary environmental risks since they are resulting from the development process of industrial society and suffer direct influence of the globalization process. They are strictly connected to the future and uncertainties. It is impossible to know precisely what the world will be like in the next few decades. Nevertheless, it is possible to calculate probabilities and scenarios. These risks are hard to predict, to avoid, to calculate, to reverse and to see. They are both local and global and threaten all humanity. Their causes and consequences are all over the world, surpassing geographical limits (Adam et al. 2000; Beck 1992, 1995, 2000, 2009, 2010; Giddens 1990, 2000, 2009; Barbi and Ferreira 2016).

Governments are important stakeholders in the process of responding to climate change risks, since they are relevant agents to outline appropriate rules, institutions and modes of governance in order to deal with these risks at different levels and scales (Giddens 2000, 2009; Bulkeley and Kern 2006; Bulkeley and Newell 2010; Ferreira et al. 2012; Ferreira and Barbi 2016).

Most of the literature on climate policy is occupied by research on global and regional levels of governance, focusing on norms, rules and decision processes regarding the international climate regime (Betsill and Bulkeley 2007; Okereke et al. 2009). Despite these necessary contributions, the local dimension of the theme is also relevant, since most human activities that contribute to global climate changes take place at this level and, at the same time, this level is the most affected by the impacts of these changes (Storbjörk 2007; Dodman 2009; Satterthwaite 2010; Hoornweg et al. 2011; Barbi and Ferreira 2013).

Climate change is a multilevel challenge since this issue permeates different interconnected levels of government (Ferreira and Barbi 2016). Without undermining the role of climate policy at a national level, subnational governments (state and municipal) represent important forums and enablers of global climate governance. The nation-states no longer monopolize the formulation of policies, which also happens because of the need for collective decision-making on complex problems and because subnational governments are interconnected by policy networks. Thus, the multilevel governance perspective becomes an alternative approach to the analysis of the role of subnational governments in the development of climate policy (Bulkeley and Betsill 2003; Gupta 2007).

Climate change risks can be minimized by reducing greenhouse gas (GHG) emissions, i.e. mitigation, or by adapting to their impacts, i.e. adaptation. Climate change mitigation and adaptation to climate change impacts are considered complementary aspects of climate change policies (IPCC 2007; Renn and Klinke 2012; Barbi and Ferreira 2016).

Biofuels, renewable energy, energy efficiency, low-carbon agriculture, carbon market, changes in consumption patterns and waste reduction help to minimize and stabilize GHG emissions. Hence, mitigation actions include all human activities intended to reduce GHG emissions or increase GHG sinks (IPCC 2007; Klein et al. 2005; IPCC 2001; Barbi and Ferreira 2016). The main obstacles to implement these policies include the emission reduction costs and political will (Winkler et al. 2007; Barbi and Ferreira 2016). Other influences on mitigation policies include experts/ 
non-experts relations, regulators/industry relations, risk perception, power and influence of interest groups and historical culture (Burch and Robinson 2007; Ferreira and Barbi 2016).

Literature on this issue (Bulkeley and Kern 2006; Betsill and Bulkeley 2007; IPCC 2007; Winkler et al. 2007; Burch and Robinson 2007; Bizikova et al. 2010; UN-HABITAT 2011) identifies five key sectors that concentrate on the responses to climate change mitigation at the subnational level: urban development (territory planning strategies), built environment, urban infrastructure (power systems, water, sanitation and solid waste), transport and carbon sequestration (conservation, reforestation, etc.).

Climate change adaptation regards adjusting natural or human systems to respond to climate change impacts, focusing on dealing with their consequences. Thus, vulnerability can be reduced by adaptation in the short and long term (IPCC 2007; Klein et al. 2005; IPCC 2001; Adger et al. 2003).

Considering climate change risks, the key sectors for adaptation responses at the subnational level are as follows: urban development (land use management); built environment; urban infrastructure and services; environment; health and disaster management. This shows the diversity of possible and necessary actions at subnational level and also the variety of government sectors involved in these two aspects of climate policy.

Addressing such a multifaceted challenge as climate change, solutions are also expected to be multifaceted, including diverse fields of human activity and several stakeholders and sectors of society, for instance: multilateral agencies, governments, private sector, research institutes and organized civil society groups aiming to elucidate the facts that generate these risks and to come upon the conditions for their confrontation (Bulkeley and Newell 2010; Barbi and Ferreira 2014, 2016).

Another relevant point for analysis of climate policies at the subnational level is the transnational networks of governments specifically related to climate change. They promoted the possibility of an urban approach to climate governance (Schroeder and Bulkeley 2008). At the time they emerged, in the 1990s, three networks played a key role: cities for climate protection (CCP) ICLEI, climate alliance for European cities (alliance for climate European cities) and energy cities (formerly energie-cites). In the 2000s, these networks developed and became broader and more politically significant also with the appearance of the C40 network, in 2005. They have provided subnational governments with inspiration, information, experience, concrete projects, access to finance, examples of good practices and informal structures of recognition and rewards, which have led to significant responses of these governments worldwide. The participation of subnational governments in these networks is a possible path with great potential for the development of effective policies and actions as responses to climate change in urban areas (Lindseth 2004).

The aim of this article was to add to the literature on subnational political strategies regarding climate change by presenting a detailed case study aimed at the analysis of climate change subnational actions in Brazil. The particular focus of attention is the analysis of how Brazilian municipal and state governments have developed and implemented climate change mitigation and adaptation public policies. This study can provide elements to efforts that seek to compare these 
strategies across countries in order to draw a composite global picture of emergent climate change actions at the subnational level.

Brazil is an important player when it comes to climate change governance because of its significant GHG emissions. Brazilian GHG emissions accounted for $5 \%$ of global emissions in 2008, when the country was the 5th largest world emitter (OC 2014; Barbi 2016). At the same time, national, state and municipal GHG emissions are different within the country and come from different sectors of activity. Therefore, mitigation policies should consider these differences across scales. Moreover, climate change impacts are felt differently depending on the scale and locality and also involve different sectors of activity depending on the level of governance, as it will be explored in the following sections.

\section{Methodological Aspects}

In terms of methodology, we conducted a survey of Brazilian municipalities and states with specific and approved legislation to address the climate issue until 2016. Therefore, the analysis of state and municipal policies is based on the following characteristics related to climate governance discussed previously:

1. climate change mitigation actions: presence of specific GHG emission reduction targets or intention;

2. climate change adaptation actions: intention to develop adaptation plans;

3. articulation among stakeholders: presence of climate forum or institutional arrangements with several stakeholders' participation in the development and elaboration processes of climate policy;

4. multi-sectorality in policy implementation: policies implemented by several climate-related sectors of municipal and state government;

5. participation of governments in transnational climate change networks.

\section{Results}

This section is divided into two parts. First, the municipal policies related to climate change risks are presented. Next, the climate change state policies are discussed.

\subsection{Political Responses to Climate Change Risks in Brazilian Cities}

The first municipal climate change policy is from 2003, in Palmas, Tocantins. However, the most important policy came in 2009, a pioneer in the country to establish concrete targets for reducing GHG emissions. This was in the city of São Paulo, and it influenced the State of São Paulo and the national policies to also set reduction targets in the same year. Other cities with climate policies in Brazil are Belo Horizonte, in Minas Gerais, Feira de Santana, in Bahia, Recife, in Pernambuco and Rio de Janeiro, in Rio de Janeiro (Barbi and Ferreira 2013). All of them were 
approved in the period from 2011 to 2014. Figure 1 shows the cities with approved climate change policies in Brazil.

The policies of Belo Horizonte, Recife, Rio de Janeiro and São Paulo established targets of GHG emission reduction and deadlines (Barbi and Ferreira 2013). The policy of Belo Horizonte (n. 10.175/2011) establishes the reduction of $30 \%$ of the municipality's GHG emissions by 2015 . The GHG inventory will be elaborated by 2016 in order to follow up the cities' emissions. The sectors involved in the mitigation strategies are the following: transport, energy, solid waste and construction. The policy of Recife (n. 18011/2014) establishes the reduction target of $14.9 \%$ in 2017 and $20.8 \%$ in 2020 , based on the 2012 emissions. The policy of Rio de Janeiro (n. 5248/2011) determines the progressive reduction of emissions by up to $8 \%$ in 2012 to $16 \%$ in 2016 and $20 \%$ in 2020, compared to emissions recorded in 2005. The mitigation strategies involve solid waste, transport and energy sectors. São Paulo established the goal of $30 \%$ reduction of GHG emissions by 2012, based on 2005. Instead of decreasing, emissions increased during this period, mainly due to the increase of the car fleet. This is the great challenge for the city. Although the policy in Feira de Santana (n. 3169/2011) does not set goals, it aims to reduce GHG

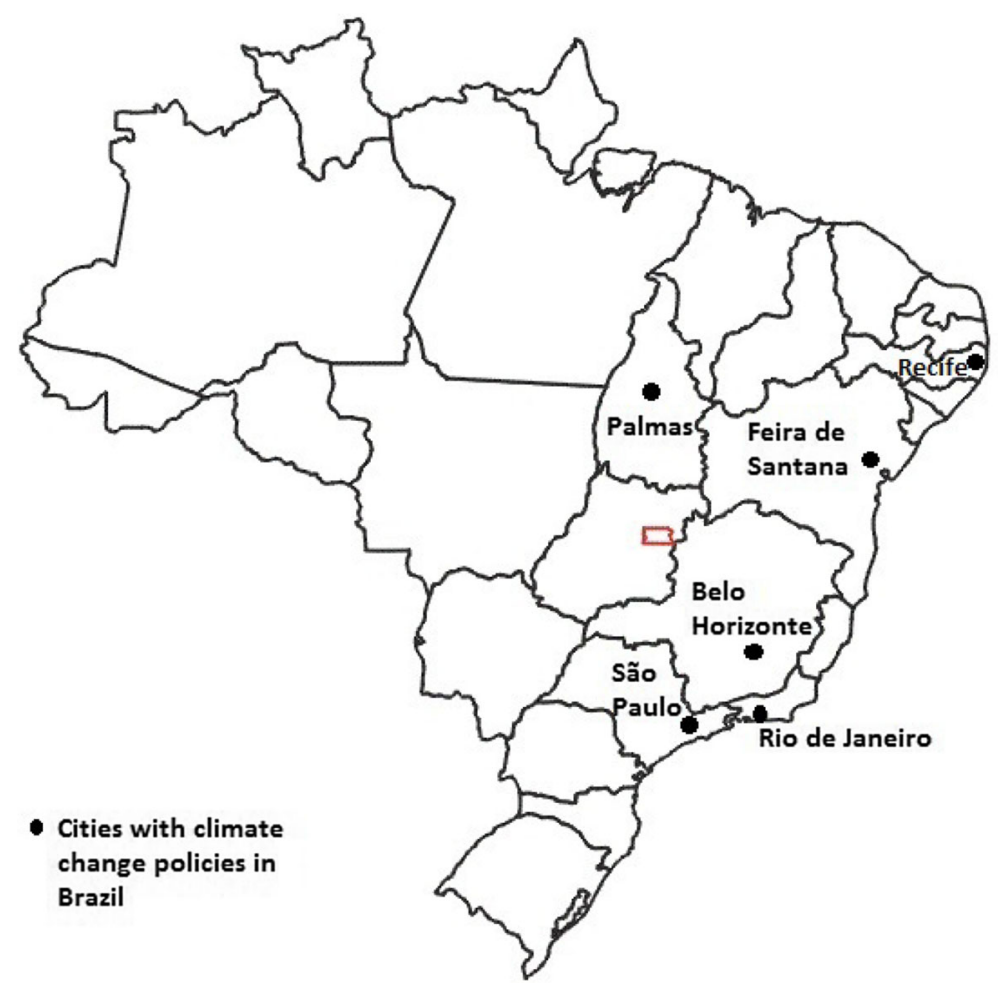

Fig. 1 Cities with approved climate change policies in Brazil. Source: Elaborated by the authors, based on Barbi and Ferreira (2013) 
emissions. The policy of Palmas (n. 1182/2003) does not define goals, but it aims to regulate projects related to forestry and energy targeting GHG emissions reduction.

Regarding adaptation, the policies of Belo Horizonte, Recife, Rio de Janeiro and São Paulo plan the establishment of an adaptation policy. The promotion of adaptation strategies in Belo Horizonte should involve civil defense, land use and health sectors. Recifés adaptation plan is yet to be defined. In the case of Rio de Janeiro, the municipal civil defense is in charge of activities related to adaptation. In São Paulo, adaptation strategies involved mainly the requalification of housing in risk areas and the recovery of permanent preservation areas, in order to prevent or minimize the risks of extreme weather events. Feira de Santana's policy is the vaguest, determining only that it aims to "define and implement measures to promote adaptation". Palmas' policy makes no mention of actions or adaptation plans, either.

Belo Horizonte, Recife, Rio de Janeiro and São Paulo counted on institutional arrangements that allowed the articulation of different stakeholders from different segments of society in the policy-making process. In Belo Horizonte, the debates regarding the climate policy started in 2006 when the Municipal Committee on Climate Change and Eco-efficiency was created under the city government, connected to the Department of Environment (Barbi and Ferreira 2013). The Committee was created to give advice, consultancy and articulate existing environmental policies in different municipal agencies to reduce GHG emissions.

In Recife, the articulation around the policy started in 2013, with the formation of two municipal forums: Comclima and Geclima. Comclima is comprised of stakeholders from the local, state and federal government, academia and organized civil society. Geclima counts on representatives from the local government from different sectors of activity. Both groups are coordinated by the Department of Environment and are intended to subsidize the municipality in issues involving climate change.

In Rio de Janeiro, negotiations on the policy were reinforced by the municipal forum on climate change in 2009 (Barbi and Ferreira 2013). The institutional structure of the Forum follows the same as the Brazilian Forum on Climate Change, with the participation of several stakeholders. The main purpose of these forums is the articulation to the development and establishment of a climate policy. Currently, the Forum of Rio de Janeiro is one of the key agents of management and consolidation of the climate policy.

In São Paulo, the discussion about the climate policy began in 2005 with the formation of the Municipal Committee on Climate Change and Sustainable Ecoeconomy, an initiative of the local government, with the aim of promoting and encouraging actions related to the mitigation of GHG emissions (Barbi and Ferreira 2013). The elaboration process of the policy took 4 years and involved the participation of stakeholders who were actively involved, such as the Department of Environment, the Research Center for Sustainability of Foundation Getulio Vargas, ICLEI-local governments for sustainability and Fabio Feldmann consultants (Barbi 2015).

Feira de Santana did not have this kind of institutional arrangement before the law was passed. However, the policy provides for the establishment of the Forum on 
Climate Change "for the manifestation of social movements, scientific sector, the business sector and all others interested in the subject, in order to promote transparency of the process and social participation in the development and implementation".

In the case of Palmas, the approval of the law took place without the participation of other stakeholders, at a time when the city was looking for a tool that would allow the sale of carbon credits and hiring consultants to carry out projects in the area of climate change, which was possible through the law (Almeida et al. 2012).

Regarding the implementation of the policies in Belo Horizonte, Recife, Rio de Janeiro and São Paulo, climate governance can be considered multi-sectoral. In this case, these municipalities counted on an institutional arrangement prior to the approval of the law, with a multi-sectoral profile for conducting the policy. In Belo Horizonte, the Municipal Committee on Climate Change and Eco-efficiency is responsible for implementing the policy, with the participation of other sectors of the municipal and state governments, representatives of the City Council, universities, NGOs and organizations representing industry and commerce.

In Recife, the implementation of the policy counted on the elaboration of a lowcarbon plan, which had the participation of the civil society, the private sector and several sectors of municipal and state governments.

In the case of Rio de Janeiro, although the policy is coordinated by the Department of Environment, its implementation is through its Climate Change and Sustainable Development Unit, in a crosscutting manner and with the participation of several areas of the municipal administration and partnerships with academic institutions. For example, the Vulnerability Map of Rio de Janeiro Metropolitan Area, which identifies the impacts on the physical environment and their respective vulnerabilities in socio-economic and natural systems, was elaborated in partnership with the National Institute for Space Research (INPE) and the University of Campinas (Unicamp) (INPE et al. 2011).

As a result of the policy in São Paulo, the following work groups were created under the municipal committee of climate change and eco-economy: transport, energy, construction, land use, waste and health. They were responsible for the preparation of the Guidelines for mitigation and adaptation to climate change, in order to detail the strategies prescribed by the policy.

In Feira de Santana, the execution of the policy is connected to the preparation of the Municipal Plan on Climate Change by the Department of Environment and Natural Resources, under the coordination of the Municipal Council of Environmental Defense. Its preparation should rely on public consultations through the Climate Change Forum. In Palmas, the implementation of the policy is responsibility of the Department of Environment and Public Services.

Finally, Belo Horizonte, Palmas, Recife, Rio de Janeiro and São Paulo are members of the cooperation network ICLEI-local governments for sustainability and were members of ICLEI's CCP campaign (cities for climate protection). Palmas participated in the campaign between 2002 and 2004, when its policy was approved. The other cities are still part of the network. Under the CCP campaign, Belo Horizonte and São Paulo joined the project "Sustainable Construction Policies (PoliCS)" with the goal to determine the commitment of these cities in the 
elaboration and implementation of sustainable building policies, focusing on energy efficiency and the promotion of low-carbon technologies. They also participated in the project "Model Communities in Local Renewable Energies (Rede Elo)" in order to reinforce the generation and use of energy from renewable sources and energy efficiency, focusing on the roles and responsibilities of local government as a driving force for technological innovation and investment in sustainable development. São Paulo also joined the projects "Green and Healthy Environment (Pavs)" and "Promoting sustainable public procurement in Brazil (CPS-Brazil)" aimed to change consumption patterns by the government. Recife participated in the project "Urban Leds", aimed at urban development based on low GHG emissions (Barbi and Ferreira 2013).

Rio de Janeiro hosted ICLEI in Brazil for 6 years and São Paulo hosted the network after that, from 2007 until 2012. They are also members of the C-40 network. Cities benefit from such involvement with cooperation networks because of the experience exchange with cities from all over regarding actions and strategies related to climate change (Martins and Ferreira 2011; Barbi and Ferreira 2013). In addition, by occupying such positions, these cities must set targets and goals regarding climate change mitigation and adaptation. Table 1 summarizes the main characteristics of climate policies in Brazilian municipalities.

Most climate policies in municipalities in Brazil were adopted from 2009, when the climate issue was a priority in the international political agenda. The policies in Belo Horizonte, Recife, Rio de Janeiro and São Paulo present more robustness once they regulate strategies with specific targets to both mitigate and to adapt to climate change. As discussed earlier, climate policies should combine mitigation and adaptation actions. These municipalities counted on previous mobilization regarding climate change, with the participation of several stakeholders from various societal segments. The involvement of different stakeholders is needed to deal with a

Table 1 Main features of climate policy in Brazilian cities. Source: Elaborated by the authors, based on Barbi and Ferreira (2013), Barbi (2015)

\begin{tabular}{|c|c|c|c|c|c|c|}
\hline City & $\begin{array}{l}\text { Year of } \\
\text { policy } \\
\text { approval }\end{array}$ & $\begin{array}{l}\text { Targets/ } \\
\text { intentions of } \\
\text { GHG } \\
\text { emissions } \\
\text { reduction }\end{array}$ & $\begin{array}{l}\text { Adaptation } \\
\text { strategies }\end{array}$ & $\begin{array}{l}\text { Stakeholder } \\
\text { participation } \\
\text { in the policy- } \\
\text { making } \\
\text { process }\end{array}$ & $\begin{array}{l}\text { Multi-sectoral } \\
\text { policy } \\
\text { implementation }\end{array}$ & $\begin{array}{l}\text { Participation } \\
\text { in climate } \\
\text { networks }\end{array}$ \\
\hline $\begin{array}{l}\text { Belo } \\
\text { Horizonte }\end{array}$ & 2011 & $X$ & $X$ & $\mathrm{X}$ & $X$ & $X$ \\
\hline $\begin{array}{l}\text { Feira de } \\
\text { Santana }\end{array}$ & 2011 & $X$ & - & - & - & - \\
\hline Palmas & 2003 & - & - & - & - & $\mathrm{X}$ \\
\hline Recife & 2014 & $\mathrm{X}$ & $\mathrm{X}$ & $\mathrm{X}$ & $\mathrm{X}$ & $\mathrm{X}$ \\
\hline $\begin{array}{l}\text { Rio de } \\
\text { Janeiro }\end{array}$ & 2011 & $X$ & $X$ & $X$ & $\mathrm{X}$ & $\mathrm{X}$ \\
\hline São Paulo & 2009 & $\mathrm{X}$ & $X$ & $\mathrm{X}$ & $\mathrm{X}$ & $X$ \\
\hline
\end{tabular}


complex issue as the climate issue. It is noteworthy that most of the analyzed policies refer to the climate change in a multi-sectoral way in their implementation, an important characteristic since the climate issue is not exclusively a responsibility of the environmental sector. Combined with this, most cities are members of climate related cooperation networks, which shows the relevance of this kind of engagement in the development and approval of climate policies.

\subsection{Political Responses to Climate Change Risks in Brazilian States}

The first state to approve their climate change policy were Amazonas, in 2007, Tocantins, in 2008, and Goiás, Santa Catarina and São Paulo, in 2009, even before the National Policy on climate change was approved in December, 2009. Since this period, the approval of climate policies has been intensified: 14 out of the 27 Brazilian states have approved their climate policy (see Fig. 2). Out of these, only Paraíba, Rio de Janeiro and São Paulo have established targets to reduce GHG emissions. However, some other policies also have intention to stabilize or reduce GHG emissions. In such cases, the policies provide for the development of mitigation plans that will set GHG emission reductions goals. Most policies, nine of them, have the intention to develop an adaptation plan to the impacts of climate

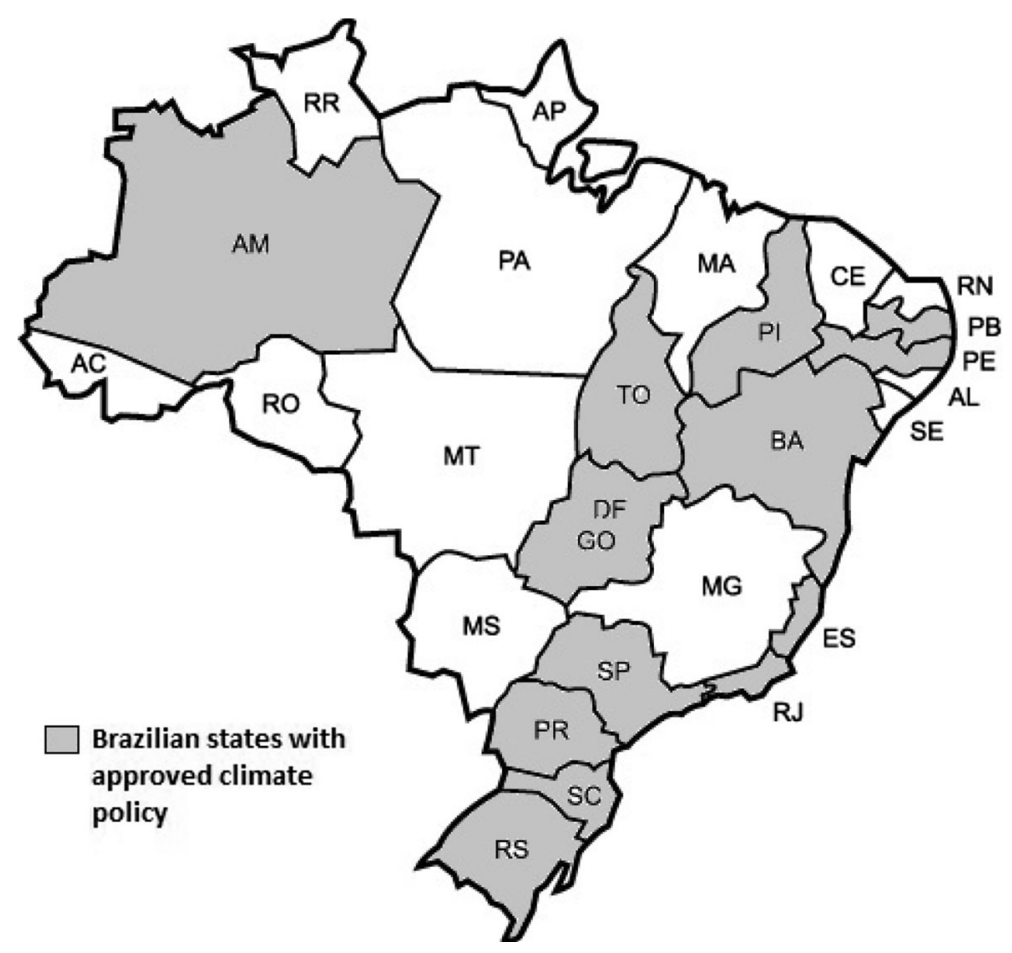

Fig. 2 Brazilian states with approved climate change policies. Source: Elaborated by the authors 
change. The only policies that cover these two aspects of climate policy are Distrito Federal, Paraíba, Rio de Janeiro and São Paulo.

In the case of state policies, the State Forums of Climate Change were fundamental for their approval: 16 states have created their Forum between 2005 and 2009, and 12 out of 14 states with climate legislation had a climate forum before their policy was approved. Only Amazonas created its Forum after the approval of the state policy on climate change. The State Forums are planned in the Brazilian Forum of Climate Change, the national forum established in 2000. They focus on regional complementation and acting in accordance with state specifications. The importance of this institutional arrangement is the possibility of dialogue between the government and the society in the search for incorporating climate change issues in the different stages of public policy.

The Brazilian Forum is chaired by the President of the country. In the case of states, the governors preside over them. They also include the participation of civil society organizations, universities and research institutes and the private sector.

Regarding the climate policy implementation, 11 out of the 14 states have assumed a multi-sectoral perspective of climate governance by creating multithematic spaces of sectoral coordination, which involve several departments and stakeholders from different segments of society and consider climate change a cross-action issue. Amazonas, Espírito Santo and Paraná have chosen to create specific institutional structures to address the climate issue and coordinate the implementation of the policy.

Finally, eight of the states participate in transnational cooperation networks related to the climate issue. Table 2 shows the main characteristics of Brazilian states' climate policies.

The states of Bahia, Pernambuco, São Paulo and Rio de Janeiro joined the cooperation network ICLEI-local governments for sustainability through projects within the CCP campaign. Bahia and Pernambuco joined the project "State Policies for Climate", whose focus was to support state action to tackle climate change. As a result of the project, these states have instituted and strengthened their forums. Bahia and Pernambuco approved their policies and Mato Grosso, also part of the project, presented the bill of the state policy on climate change. São Paulo and Rio de Janeiro integrated projects on sustainable public procurement, focusing on the use of state purchasing power as an important tool to implement climate change policy.

The states of Paraná, Rio de Janeiro, Rio Grande do Sul, São Paulo and Tocantins are members of the network of regional governments for sustainable development (NRG4SD). The network has a working group on climate change directed to the territorial dimension of the international carbon market mechanisms.

\section{Discussion}

This article presents and analyzes the profile of policy responses in Brazilian subnational governments to climate change. By 2016, 6 municipalities out of 5570 and 14 states out of 27 had a specific approved legislation related to the climate 


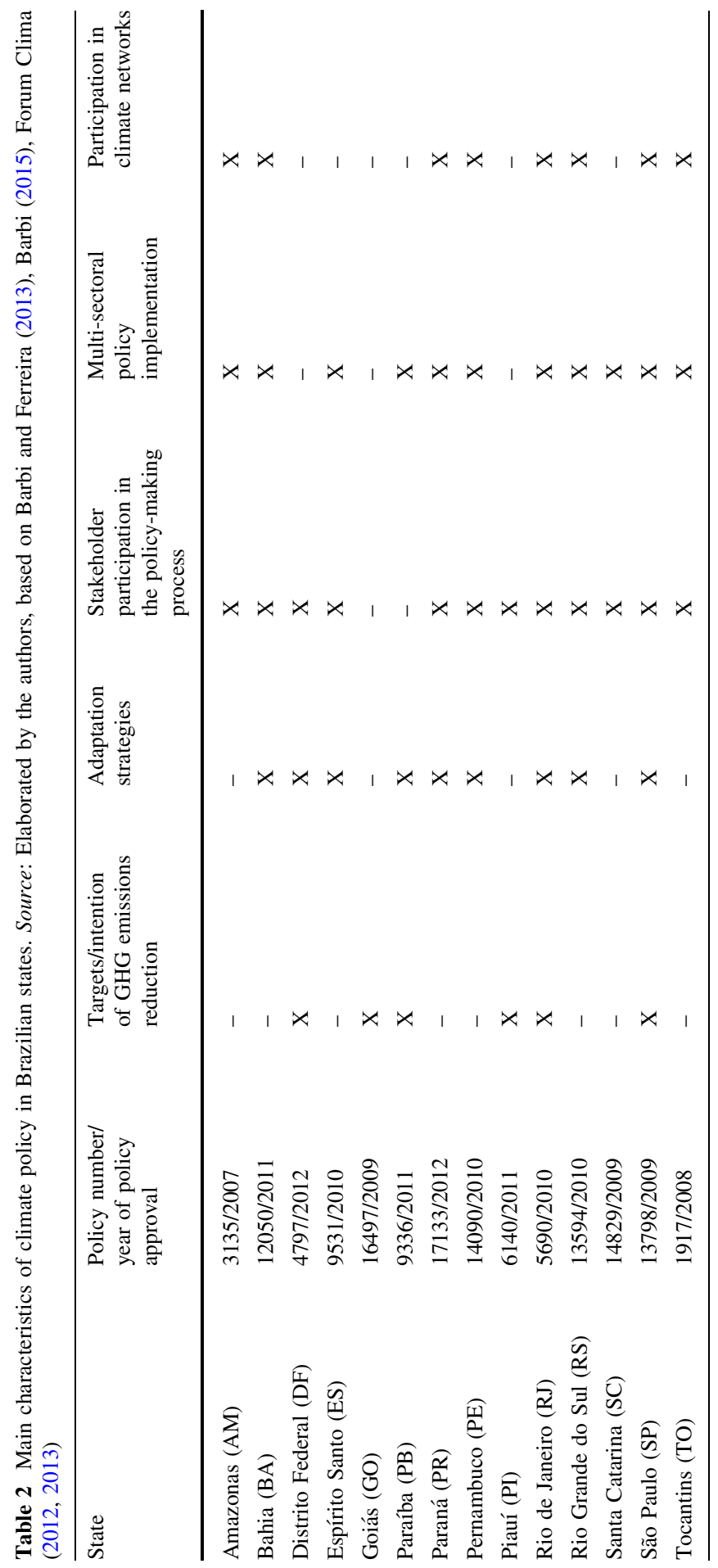


issue. Most of them were approved from 2009 on, at a time when the climate issue was a priority in the international political agenda, by the time of the conference of the parties (COP) in Copenhagen.

Following the growing international movement of subnational responses to climate change (Bulkeley and Newell 2010), in Brazil, this type of action was more expressive first at the city level. Then, it reached the state level and finally, the federal level. In this movement, the climate policy of the city of São Paulo had a leading role, since it was the first one to establish GHG reduction targets, influencing the approval of the state policy, which also exerted influence on the federal policy process of approval (Barbi and Ferreira 2013).

Brazilian subnational policies are isolated initiatives in the national context. Thus, according to the results shown not all policies include the two main aspects of climate policy, that is, mitigation and adaptation.

Brazil is a significant country in the global climate change scenario. Brazilian GHG emissions represented 5\% of global emissions in 2008, placing the country as the 5th largest world emitter. The biggest responsible sector for Brazilian emissions over 20 years was land use change and forestry. This sector responded for $58 \%$ of national emissions in 2005. However, this has changed when emissions from this sector reached $15 \%$ of total emissions in 2012, because of Amazon deforestation reduction since 2004. At the same time, emissions from other sectors of activity increased during this time. Energy and agriculture were the sectors with greatest increase in emissions from 2005 to 2012. Energy emissions represented 29\% of Brazilian emissions in 2013 (Barbi 2016).

These data show that there has been an important change in the GHG emissions profile in the country. Therefore, mitigation strategies should follow this change. They should not only keep the focus on the land use change and forestry sector-on decreasing deforestation, but they should also include energy and agriculture sectors which have increased their contribution to GHG emissions. In this sense, subnational mitigation measures are fundamental. For instance, Amazon states and cities play a key role in defining and implementing strategies aimed at land use change and forestry emissions while Southeastern states and cities, like São Paulo, are more important regarding mitigation actions related to the energy sector. Subnational emissions come from different sectors of activities all over the country. Therefore, national climate change mitigation policies should be articulated with subnational mitigation guidelines concerning regional emission profiles. This is also essential to ensure that Brazilian emissions will be reduced and that the national policy on climate change will be successful. According to our results, only five cities and six states in the country have intentions or targets to reduce GHG emissions.

Regarding the adaptation aspect of climate policies, it is important to emphasize that Brazil has a coast of almost $7500 \mathrm{~km}$, where many and some of the most important cities in the country are located and where most of the population is concentrated. Moreover, coastal regions are considered the most vulnerable areas to the impacts of climate change, due to their geographical specificity, i.e. the interface among continent, atmosphere and ocean and because they are places with high concentrations of people and structures. According to our results, only two coastal 
cities in Brazil (Recife and Rio de Janeiro) have an adaptation strategy in their climate policy.

Subnational adaptation policies are fundamental to address social, economic and environmental vulnerability in each part of the country, since the impacts of climate change are different for each region. For instance, the population in the Northeast of the country is the most vulnerable to climate change because of its social and economic development low levels. This assessment is based on the assumption that population groups with worse income, education and housing would suffer the greatest impacts of environmental and climate changes (PBMC 2013). According to the results presented, only three states and one city in the Northeastern region have adaptation strategies. This is not enough to face the challenges that are expected in the region and in the country, as consequences of climate change. Extreme events of rainfall are expected to affect many regions in Brazil. As a consequence, landslides are expected to grow and they are already the major cause of deaths from natural disasters $(60 \%)$, followed by floods.

Moreover, the economic costs of climate change impacts are high within the country. It is estimated that in the Center-Western region of the country these costs could reach $4.5 \%$ of the GDP in $2050 ; 3.1 \%$ of the GDP for the Northern region; $2.9 \%$ for the Northeastern region and $2.4 \%$ for the Southeastern region (PBMC 2013). Once again, subnational adaptation strategies are key to reduce social, economic and environmental vulnerability and should be articulated with the national strategies in order to be successful.

An important point in the case of the approved subnational policies was the existence of previous institutional arrangements with several stakeholders, such as the Municipal Committees and the Municipal and State Forums of Climate Change. They allowed the articulation among different stakeholders and sectors of activity involved in the climate issue and played a key role in the elaboration and adoption of climate policies.

Moreover, most of the subnational policies focus on the multi-sectoral nature of policy implementation, a relevant characteristic regarding the climate issue since it permeates the different sectors of government action. This fact demonstrates a better understanding of the climate issue by these governments, since this issue is not solely related to the environmental sector of governmental structures, but also involves sectors related to urban development and infrastructure, transport, carbon sequestration, disaster management and health.

Another point to be noted was the participation in transnational cooperation networks linked to climate change, which occurs in most municipalities and states with climate policies and in all of them with both mitigation and adaptation actions. Certainly, this factor also contributed to the approval of policies in these cases.

Added to this, both at municipal and at state level there were ongoing actions related to climate change which were consolidated and better articulated when they were incorporated into a specific climate policy (Barbi 2015). It is noteworthy, therefore, to stress the importance of a specific policy to address the climate issue and provide greater consistency and effectiveness to these actions.

Although few Brazilian municipalities and states approved a specific climate policy, the experiences presented in this paper can be considered relevant initiatives 
to deal with the problem in the country and the most robust policies that count on mitigation targets, adaptation plans and multi-sectoral implementation could be extended to other municipalities and states within the country.

\section{Conclusions}

Climate change risks set up an unprecedented challenge to contemporary societies and responding to them will greatly influence the future life on the planet. Within the understanding of the social and political dimensions of the climate issue, this article highlighted governments as relevant stakeholders in proposing appropriate forms of climate governance, considering that they are not the only ones facing this challenge. However, emphasizing the importance of this stakeholder does not mean defending a "top-bottom" government.

A specific group of stakeholders, such as subnational governments, cannot solve the climate crisis, since this is a complex, multilevel and multidimensional problem. The intent of this article was to deepen the knowledge about the role of subnational governments in the Brazilian context as key players, but not the only ones. The involvement of non-governmental stakeholders, organizations of civil society, the private sector, universities and research institutions is critical to the production of efficient and successful responses to the problem.

This article analyzed how Brazilian municipalities and states have responded to the challenge of climate change risks. Even though these initiatives are important, they are not enough facing climate scenarios presented by scientists (Rogelj et al. 2016).

Every action and political intervention at all different levels of governance have a determining effect on tackling climate change. The establishment of climate policies is the first step; however, the law enforcement is fundamental in this process to ensure that mitigation and adaptation actions are taken.

The inclusion of the climate change issue into the political agenda is considered a first movement of societal response (Giddens 2009). The introduction of this issue in institutions and daily concerns of citizens characterizes the next movement. Definitely, there is a lot to be done in this regard.

The social and political dimensions of climate change have shown to be important extensions of research, given the complexity of the relationship between knowledge, policy recommendations and changes in current development standards.

\section{References}

Adam, B., U. Beck, and J.V. Loon. 2000. The risk society and beyond: Critical issues for social theory. London: Sage Publications.

Adger, W.N., S. Huq, K. Brown, D. Conway, and M. Hulme. 2003. Adaptation to climate change in the developing world. Progress in Development Studies 3 (1): 179-195.

Almeida, L.A., M.A.R. Silva, R.A.C. Pessoa. 2012. Políticas Públicas, Mudanças Climáticas e a participação de cidades em Redes Transnacionais: o caso de Palmas-TO. In Paper presented at VI Encontro Nacional da Anppas, Belém, Brazil. 
Barbi, F. 2016. Governing climate change in China and Brazil: Mitigation strategies. Journal of Chinese Political Science 21 (1): 357-370.

Barbi, F. 2015. Mudanças climáticas e respostas políticas nas cidades. Campinas: Editora da Unicamp.

Barbi, F., and L.C. Ferreira. 2013. Climate change in Brazilian cities: Policy Strategies and responses to global warming. International Journal of Environmental Science and Development 4 (1): 49-51.

Barbi, F., and L.C. Ferreira. 2014. Risks and political responses to climate change in Brazilian coastal cities. Journal of Risk Research 17 (4): 485-503.

Barbi, F., and L.C. Ferreira. 2016. Governing climate change risks: Implications for mitigation and adaptation. Fudan Journal of the Humanities and Social Sciences 9 (4): 589-606.

Beck, U. 2010. Climate for change, or how to create a green modernity? Theory, Culture \& Society 27 (2-3): 254-266.

Beck, U. 1995. Ecological politics in an age of risk. Cambridge: Wiley.

Beck, U. 2000. Risk society revisited: Theory, politics and research programmes. In The risk society and beyond: Critical issues for social theory, ed. B. Adam, U. Beck, and J.V. Loon. London: Sage Publications.

Beck, U. 1992. Risk society: Towards a new modernity. Beverly Hills: Sage.

Beck, U. 2009. World at risk. Cambridge: Polity Press.

Betsill, M.M., and H. Bulkeley. 2007. Looking back and thinking ahead: A decade of cities and climate change research. Local Governments 12 (5): 447-456.

Bizikova, L., S. Burch, S. Cohen, and J. Robinson. 2010. Linking sustainable development with climate change adaptation and mitigation. In Climate change, ethics and human security, eds. K. L. O'brien, A. L. St. Clair, B. Kristoffersen. Cambridge: Cambridge University Press.

Bulkeley, H., and M. Betsill. 2003. Cities and climate change-Urban sustainability and global environmental governance. New York: Routledge.

Bulkeley, H., and K. Kern. 2006. Local Government and the governing of climate change in Germany and the UK. Urban Studies 43 (12): 2237-2259.

Bulkeley, H., and P. Newell. 2010. Governing climate change. New York: Routledge.

Burch, S., and J. Robinson. 2007. A framework for explaining the links between capacity and action in response to global climate change. Climate Policy 7 (4): 304-316.

Dodman, D. 2009. Blaming cities for climate change? An analysis of urban greenhouse gas emissions inventories. Environment and Urbanization 21 (1): 185-198.

Ferreira, L.C., R.D. Martins, F. Barbi, A.M. Urbinatti, F.O. Souza, T.H. Andrade, and L.F. Mello. 2012. Risk and climate change in Brazilian coastal cities. In Risk and social theory in environmental management, ed. T.G. Measham, and S. Lockie, 133-146. Collingwood: CSIRO.

Ferreira, L.C., and F. Barbi. 2016. The challenge of global environmental change in the anthropocene: An analysis of Brazil and China. Chinese Political Science Review 1 (4): 685-697.

Fórum Clima. 2012. Ação empresarial sobre mudanças climáticas. O Desafio da Harmonização das Políticas Públicas de Mudanças Climáticas. São Paulo.

Fórum Clima. 2013. O Desafio da Harmonização das Políticas Públicas de Mudanças Climáticas. Volume II. São Paulo.

Giddens, A. 2000. Runaway world. How globalization is reshaping our lives. New York: Routledge.

Giddens, A. 1990. The consequences of modernity. Stanford: Stanford University Press.

Giddens, A. 2009. The politics of climate change. Cambridge: Polity Press.

Gupta, J. 2007. The multi-level governance challenge of climate change. Journal of Integrative Environmental Sciences 4 (3): 131-137.

Hoornweg, D., L. Sugar, and C.L.T. Gomez. 2011. Cities and greenhouse gas emissions: Moving forward. Environment and Urbanization 23 (1): 207-227.

INPE, UNICAMP, SMAC. 2011. Vulnerabilidades das Megacidades Brasileiras às Mudanças Climáticas: Região Metropolitana do Rio de Janeiro.

IPCC-Intergovernmental Panel on Climate Change. 2007. Summary for Policymakers. In Climate Change 2007: Mitigation. Contribution of Working Group III to the Fourth Assessment Report of the Intergovernmental Panel on Climate Change, eds. B. Metz, O.R. Davidson, P.R. Bosch, R. Dave, and L.A. Meyer. Cambridge, United Kingdom and New York, USA: Cambridge University Press.

IPCC-Intergovernmental Panel on Climate Change. 2001. Summary for policymakers-climate change 2001: Impacts, adaptation, and vulnerability. In A Report of Working Group II of the Intergovernmental Panel on Climate Change. 
IPCC-Intergovernmental Panel on Climate Change. 2013. Working Group I Contribution to the IPCC Fifth Assessment Report. Climate Change 2013: The Physical Science Basis. Summary for Policymakers.

Klein, R.J.T., E.L.F. Schipper, and S. Dessai. 2005. Integrating mitigation and adaptation into climate and development policy: Three research questions. Environmental Science \& Policy 8 (1): 579-588.

Lindseth, G. 2004. The cities for climate protection campaign (CCPC) and the framing of local climate policy. Local Environment 9 (4): 325-336.

Martins, R.D., and L.C. Ferreira. 2011. Climate change action at the city level: Tales from two megacities in Brazil. Management of Environmental Quality: An International Journal 22 (3): 344-357.

OC_-Observatório do Clima. 2014. Análise da evolução das emissões de GEE no Brasil (1990-2012). Documento Síntese.

Okereke, C., H. Bulkeley, and H. Schroeder. 2009. Conceptualizing climate governance beyond the international regime. Global Environmental Politics 9 (1): 58-78.

PBMC. Painel Brasileiro de Mudanças Climáticas. 2013. Contribuição do Grupo de Trabalho 2 ao Primeiro Relatório de Avaliação Nacional do Painel Brasileiro de Mudanças Climáticas. Sumário Executivo do GT2. PBMC, Rio de Janeiro, Brasil.

Renn, O., and A. Klinke. 2012. Complexity, uncertainty and ambiguity in inclusive risk governance. In Risk and social theory in environmental management, ed. T.G. Measham, and S. Lockie, 59-76. Collingwood: CSIRO.

Rogelj, J., M. Elzen, N. Höhne, T. Fransen, H. Fekete, H. Winkler, R. Schaeffer, F. Sha, K. Riahi, and M. Meinshausen. 2016. Paris Agreement climate proposals need a boost to keep warming well below $2{ }^{\circ} \mathrm{C}$. Nature 534 (1): 631-639.

Satterthwaite, D. 2010. The contribution of cities to global warming and their potential contributions to solutions. Environment and Urbanization Asia 1 (1): 1-12.

Schroeder, H., and H. Bulkeley. 2008. Global cities and the governance of climate change: What is the role of law in cities? Fordham Urban Law Journal 36 (2): 312-360.

Storbjörk, S. 2007. Governing climate adaptation in the local arena: Challenges of risk management and planning in Sweden. Local Environment 12 (5): 457-469.

UN-HABITAT (United Nations Human Settlements Programme). 2011. Cities and climate change: global report on human settlements. Earthscan.

Winkler, H., K. Baumert, O. Blanchard, S. Burch, and J. Robinson. 2007. What factors influence mitigative capacity? Energy Policy 35 (1): 692-703.

WMO_-World Meteorological Organization. 2013. The Global Climate 2001-2010: A decade of climate extremes. Genève.

Zwiers, F. W., L. V. Alexander, G. C. Hegerl, T. R. Knutson, P. Naveau, N. Nicholls, C. Schar, S. I. Seneviratne, and X. Zhang. 2013. Climate Extremes: Challenges in Estimating and Understanding Recent Changes in the Frequency and Intensity of Extreme Climate and Weather Events. In Climate Science for Serving Society: Research, Modeling and Prediction Priorities, eds. G. R. Asrar, and J. W. Hurrell, 339-389. Springer: Netherlands.

Fabiana Barbi is a post-doctoral researcher in the Center for Environmental Studies and Research (NEPAM) at University of Campinas (UNICAMP), Brazil. She is a research fellow of the Earth System Governance Project.

Leila da Costa Ferreira is a full time professor in the Institute of Philosophy and Human Sciences and in the Center for Environmental Studies and Research (NEPAM) at University of Campinas (UNICAMP), Brazil. She is a faculty member of the Earth System Governance Project. 